\title{
Serum mineral concentrations in the patients of surgical intensive care unit
}

\author{
J-M Lee ${ }^{1 *}$, ES Bang ${ }^{2}$ \\ From ESICM LIVES 2015 \\ Berlin, Germany. 3-7 October 2015
}

\section{Introduction}

Concentrations of some circulating trace elements such as zinc and selenium are known to decrease significantly after severe trauma, surgery, sepsis, and severe systemic inflammatory response and decreased plasma trace elements concentrations are associated with severity of critical illness.

\section{Objectives}

We examined the value of plasma trace element, zinc ( $\mathrm{Zn})$, copper $(\mathrm{Cu})$, manganese $(\mathrm{Mn})$ and selenium $(\mathrm{Se})$ when assessing nutritional status in critically ill patients in the surgical intensive care unit (ICU).

\section{Methods}

A total of 54 patients (34 males and 20 females, mean age of 64 years old) who were admitted to surgical ICU and consulted to the nutritional support team (NST). Arterial blood samples were obtained on the day of NST consultation and every 7 days until discharge from the ICU. The concentrations of trace elements were measured at the Seoul Medical Science Institute (Seoul, Korea). The references of trace elements were like this; $\mathrm{Zn}$ (66-110 $\mu \mathrm{g} / \mathrm{dl}), \mathrm{Cu}(75-145 \mu \mathrm{g} / \mathrm{dl}), \mathrm{Mn}(4.7-18.3 \mu \mathrm{g} / \mathrm{l})$, and Se $(5.8-23.4) \mu \mathrm{g} / \mathrm{dl}$.

\section{Results}

The mean length of stay in the ICU and mortality were 22.7 days (median 14 days) and $24 \%$, respectively. The $\mathrm{Zn}$ deficiencies were detected in $72 \%$. The mean concentration of Zn on the day of NST consultation was $55.5 \pm 22.9$ $\mu \mathrm{g} / \mathrm{dl}$ and it recovered to normal range to $89.5 \pm 29.3 \mu \mathrm{g} /$ $\mathrm{dl}$ on the following day 14 after TPN and trace elements requirement drug appliance. There was $36 \%$ of $\mathrm{Cu}$ deficiency, only one case of Se deficiency and no $\mathrm{Mn}$ deficiency. Both $\mathrm{Cu}$ and $\mathrm{Mn}$ showed increased concentration in normal range; $\mathrm{Cu}: 83.7 \pm 22.2 \mu \mathrm{g} / \mathrm{dl}$ à $108.9 \pm$ $32.4 \mu \mathrm{g} / \mathrm{dl}$ and $\mathrm{Mn}: 9.4 \pm 4 \mu \mathrm{g} / \mathrm{l}$ à13.8 $\pm 3.7 \mu \mathrm{g} / \mathrm{l}$, respectively.

\section{Conclusions}

There was high incidence of Zn deficiency (72.2\%). Zn deficiency can induce the impaired wound healing, diarrhea and immunosuppression, therefore, we recommend regular checkup of serum $\mathrm{Zn}$ level and strict supplement. Compared to $\mathrm{Zn}$, other trace elements showed quite normal range of serum concentration. Further study about trace elements and nutritional status and clinical outcome in the ICU patients are needed.

\section{Authors' details}

${ }^{1}$ Ajou University School of Medicine, Suwon, Republic ofKorea. ${ }^{2}$ Ajou University Hospital, Suwon, Republic ofKorea.

Published: 1 October 2015

doi:10.1186/2197-425X-3-S1-A584

Cite this article as: Lee and Bang: Serum mineral concentrations in the patients of surgical intensive care unit. Intensive Care Medicine Experimental 2015 3(Suppl 1):A584. 